\title{
Constructing Order in the Use of Land in Coastal Water for Bajo Tribe Residence
}

\author{
Muh. Afif Mahfud ${ }^{1}$, Erlyn Indarti², Sukirno ${ }^{3}$ \\ \{afifmahfud4@gmail.com ${ }^{1}$ \} \\ Universitas Diponegoro, Indonesia ${ }^{1,2,3}$
}

\begin{abstract}
Every community strives to create order, including the use of land on the coast. This study aims to explore (1) the factors that need to be considered in land use management for Bajo Tribe community settlements and; (2) a paradigmatic study of the creation of order by the Bajo tribe in land use for settlements. This research is based on a qualitative research tradition, using primary data and secondary data. The data collected through in-depth interviews were analyzed and presented descriptively. Based on the research, it was found that: (1) In carrying out land use, it is necessary to pay attention to: (a) the relationship between the community and the land; (b) geographical conditions; (c) typical land tenure patterns. (2) A paradigmatic study of order in the traditional community settlements of the Bajo Tribe, namely (a) ontology: the traditional Bajo people identify themselves as sea people; (b) epistemology: close relations and promoting solidarity; (c) methodology: discussion creates consensus and land-use boundaries; (d) method: $1.5 \mathrm{~m}^{2}$ distance between houses and neighbor's permission.
\end{abstract}

Keywords: Order, Rule, Land Use, Coastal Sea, Bajo Tribe

\section{Introduction}

The existence of a very close relationship between the Bajo tribe and coastal waters has led this community to establish settlements in various countries' coastal waters, including Malaysia, the Philippines, and Indonesia [1]. In Indonesia, the population of the Bajo tribe reaches 467,000 people. These people inhabit the islands of Sulawesi, Kalimantan, Nusa Tenggara and Maluku [2]. Mead and Lee [3] noted that the number of Bajo people living in Sulawesi Island reached 92,000 people spread across the Provinces of North Sulawesi and Gorontalo, Central Sulawesi, Southeast Sulawesi, and also South Sulawesi.

The existence of Bajo tribe community settlements in coastal waters requires land stewardship. It cannot be separated from the definition of land in Indonesia, including land in coastal waters. Land use management as an orderly land law is crucial to create balance, order, harmony, and harmony in land use in coastal waters. Order in land stewardship is achieved by balancing individual interests and public interests [4].

This land-use management is based on Article 33 paragraph 3 of the 1945 Constitution of the Republic of Indonesia and Article 2 of Law No. 5 of 1960 concerning Basic Agrarian Principles (starting now referred to as UUPA/Basic Agrarian Law) to the state in regulating natural resource management. It is then spelled out in Article 14 of the UUPA, which gives the government authority to make a general plan for the supply, allocation, and use of land and water. This article then underlies the making of Law No. 26 of 2007 concerning Spatial Planning and Government Regulation No. 16 of 2004 concerning Land Stewardship. 
This land stewardship also includes coastal waters as a place used by the Bajo people to establish settlements. However, there have been no specific regulations governing land use in coastal waters until now. Moreover, the area is inhabited by people who have ties to the ocean's economic, social, and cultural aspects. Through this social and cultural, and even spiritual attachment, the Bajo people create their order outside of state law or written regulations made by the Government. It shows that the state, through statutory regulations, is not the only institution that creates order. Still, society will try to create its order in the absence of written regulations.

The overall description above brings the author to the main questions: (1) What factors need to be considered by the Government in conducting land use for community settlements in coastal waters? And (2) How to analyze the paradigmatic philosophy of the order created by the Bajo tribe in land use for settlements without the state's regulations?

\section{Research Methods}

This research is based on the constructivism paradigm using a qualitative research tradition that prioritizes appreciation and experience as well as intensive interaction between researchers and the Bajo people. This study uses primary data and secondary data. Preliminary data was collected through in-depth interviews with the Bajo people, while secondary data was collected through a literature study. The data obtained were then analyzed and presented descriptively.

\section{Discussion}

\subsection{Factors that the Government Needs to Pay attention to in Conducting Land Use Management for Bajo Tribe Community Settlements}

To analyze the land use management in Indonesia, the author will first state the meaning of land, namely the surface of the earth. In this case, the earth's surface is a space with two dimensions: length and width. This definition still emphasizes land space and has not touched coastal areas or coastal waters. The statement that land covers the earth's surface under the sea (including coastal waters) is only limited to the doctrine put forward by Boedi Harsono. Implicitly, the recognition that the earth's surface in coastal waters is also interpreted as land is also stated in the Regulation of the Minister of Agrarian Spatial Planning/National Land Agency No. 17 of 2016 concerning Land Arrangement in Coastal Areas.

Based on Article 1 point 1 Government Regulation No. 16 of 2004 concerning Land Use, land use management is equated with a pattern of land use management that includes control, use, and land utilization in consolidated land use through institutional arrangements. In connection with the construction of houses in coastal waters by traditional communities as a social act, it is essential to put forward the symbolic interactionism by Herbert Blumer that every individual gets external influence (information) in his life, and then the individual interprets the information. The results of this interpretation can be in the form of approving, suspending, or rejecting. In this case, the individual in the traditional society agrees with the information. Because many people agree with the story, it is transformed into a collective action called social action. 
Second, geographically, land in the coastal area used by traditional communities to establish settlements has different conditions from land conditions. Therefore, the use of land underwater requires different arrangements in terms of determining land boundaries, determining criteria for activities that can be carried out in the area, and paying attention to environmental aspects. So that land use in the area remains in line with the principle of sustainability in land stewardship. In the explanation section of Government Regulation No. 16 of 2004 concerning Land Use, the principle of sustainability means that land stewardship guarantees the sustainability of the land's function for the sake of taking into account the interests of generations.

Third, there is a unique land tenure pattern in the community. It is important to note because the law is not autonomous, does not exist in a vacuum (void), and cannot be separated from the social aspects in which the law is made and applies. In the traditional community of the Bajo tribe, which was studied, it appears that between the houses. There is always a boat channel and a part of the house, which is also unique with the existence of a place to dry the fish. This condition is, of course, important for the Government to pay attention to and accommodate. It's just that until now, the Government has not provided regulations regarding land use for traditional community settlements in coastal waters.

The previous explanation has shown that the problem is a vacuum of regulation on community settlement but this problem can be solved by society through consensus to create order. This is constructivism-based research in which law is not understood as a series of regulations created by the government but consensus which is achieved by society. In this case, Bajo tribe has made a consensus without state intervention to create order in their tribe and this consensus is obeyed by every member of that community. It means that a vacuum in regulation is not identical to a vacuum of order because every community will create its order based on consensus.

The state's absence of regulation regarding land use in general, including traditional community settlements in coastal waters, raises questions about creating order in land use in these communities. In a more specific context, the question that arises is how then the realization of the principles of land use, namely the principles of integration, efficiency and effectiveness, harmony, harmony, balance, sustainability, openness, equality, justice, and legal protection in the use of land for traditional community settlements [5].

The attainment towards orderliness is a complex endeavor and cannot be achieved only through statutory or monolithic regulations [6]. This empirical research-based article shows that the two are not identical because the traditional Bajo people as a social system will always strive to create their order, which is rooted in cosmology, communal feelings, group identity, and their need for peace and security in building houses in coastal waters. It is through this order that people can establish relationships with each other.

\subsection{Bajo Tribe Traditional Communities Create Order in the Use of Land for Settlements Without Regulations (State Law) Paradigmatic Study}

The abstract nature of the law shows that understanding the law for traditional societies has gone beyond a series of paradigms that are still in the realm of realism or are in the paradigm of constructivism. To provide a clear, comprehensive, and sharp understanding, the following authors point out the emergence of order in the traditional Bajo tribe in the absence of written regulations from the state. The study starts from the ontology, epistemology, methodology, and methods as in the following table: 
Table 1. Constructivism Paradigm

\begin{tabular}{ll}
\hline Ontology & Members of the traditional Bajo tribe have their own understanding of \\
Relativism & the ocean and identify themselves as sea people. This understanding is \\
& related and formed through experiences and from the people and society \\
& from generation to generation. It also affects land use patterns for \\
establishing settlements in coastal waters. That is, the understanding of & the traditional Bajo tribe about the ocean affects the establishment of \\
these community settlements in coastal waters.
\end{tabular}

Epistemology The traditional community of the Bajo tribe as a communalistic society Subjectivist is a collection of individuals who interact intensively with their Transactional respective subjectivities. The interaction of these societies is based on maintaining solidarity and order. In this case, the interaction seeks to create harmony in society. The desire to create peace in the interactions among the community, including concerning the construction of houses in coastal areas.

Methodology In this interaction, people express their respective understandings. This
Dialectical understanding will then be compared or even challenged to create a Hermeneutics consensus (agreement/resultant) regarding the traditional Bajo people's settlement patterns. In this case, the law is interpreted as an agreement. Based on this meaning, the law/agreement is dynamic or open. Thus, law-creating activities continue to occur in line with society's changes, including the flow of information, so that construction becomes more well informed and sophisticated.

At this point, it is necessary to provide limitations in land use and determine the established mechanism to maintain harmony in the traditional Bajo community.

Method (Practice) $\quad$ There is a distance of $1.5 \mathrm{~m}^{2}$ between houses as a boat channel and permission requests from neighbors before building a house. The construction of houses is carried out jointly by the community due to close social ties.

In the realm of ontology, the traditional Bajo people identify themselves as sea people called sama. In this society, there is a saying that the sea is where the Bajo (sama) live, while the land people (Bagai) choose land as their place to live their lives. This community has long lived on a boat called the dakampungan. This pattern is now changing by building houses on the coast. Even though traditional communities established settlements on the coast, the orientation of these traditional communities as coastal people did not change. Based on this understanding, in essence, the Bajo people's settlement symbolizes the connection between the Bajo tribe community and the ocean, which has been passed down from generation to generation through various media. Moreover, historically the traditional community settlements of the Bajo tribe have existed since the XVII century AD. In this regard, it is essential to cite [7], that every society has its understanding and legal culture regarding justice, peace, and various other matters. Culture, beliefs, and social factors play an essential role in shaping a person's attitude and understanding of order.

In the basic belief methodology, each individual of the traditional Bajo tribe with different views is then discussed in an equal position among the parties. In this discussion, there is a development of information that becomes the basis for creating an agreement or resultant. This agreement later became a guide in the use of land in the traditional Bajo tribe. The agreement 
relates to restrictions on the use of land for the traditional Bajo community. These restrictions are the basis for creating harmony in society. These boundaries are in the form of maximum land ownership limits, boundaries between land parcels, and boundaries between lands.

In the practical sphere, the distance between homes is $1.5 \mathrm{~m}^{2}$ based on a consensus of that tribe. The distance between the houses is used as a boat channel or boat path. In this case, the Bajo tribe puts the boat beside their house so that access or roads are needed for each member of the traditional community. The traditional society places the boat next to the house for safety from the boat in the event of a big wave that has the potential to damage the boat, and it is more practical because there is no need to lift fishing gear and catches from land to sea. The existence of a distance of $1.5 \mathrm{~m}^{2}$ is also essential because the transportation used daily by the traditional Bajo tribe is a canoe. This distance is also essential in supporting the community's daily transportation, not only in the context of supporting fisheries activities they carry out.

Also, in practice, the traditional Bajo people also ask their neighbors for permission before building a house. They were done to prevent conflict in the community and as a form of communalism in the society. In its communalistic nature, society emphasizes solidarity so that each individual strives to create harmony. At this point, individuals are part of society and the emphasis is on the group's interests. So that solidarity needs to be maintained by each individual. Friedman [8] stated that humans are cultural and social beings who live in an interconnected community.

The settlement of disputes in the traditional Bajo tribe also emphasizes deliberation because it is considered in line with the community's solidarity values. Moreover, this society is a small society where the pattern of relationships between individuals in this group is still closely intertwined based on kinship and also the same culture so that solidarity takes precedence [9][10]. The description above shows that the traditional Bajo tribe community has established its order by relying on its cosmology and communalistic nature. This order is achieved through a consensus that is dynamic and open but at the same time complex. Olivecroa and Lund lent call it a re-examination process and re-definition [11].

This consensus is the law for the community. At the same time, this condition proves that state law is not the only instrument in creating an order. Rahardjo [12] even stated that state law (rules) only occupies a small part of the universe of order. If state law is to place itself as the only source of order, the state law will fail. The Bajo tribe is a participant community because it relies on consensus and cooperation between all society components; there are no institutions with special obligations, decision-making is carried out by the majority of the population who are adults and goal-oriented.

The existence of order in the traditional Bajo tribe community is a combination of three orders: habits, laws (agreements), and morals. In terms of habits, traditional societies are accustomed to living in the sea and establishing settlements in coastal waters. This habit is related to the law because the law itself is institutionalizing habits that the community owns through an agreement. As for decency, it is in the ideal realm, namely, a solid society [13].

Based on the mirror thesis, the law should pay attention to aspects of morality, rationality, habits, and consent or what society agrees. If the level of reflection on these four things is high, then the law will be accepted by society and will be effective. In the view of anthropology, the law is a socio-cultural manifesto [14]. On the other hand, if the law does not reflect this, society will reject it. In facing this condition, the state should be present to recognize the law, which is understood as a consensus in traditional communities such as the Bajo tribe. Through this, the law becomes contextual. The state should not be present by identifying itself with an order but by providing space to create order following the community's understanding and culture $[15][16]$. In the development of national law, it is necessary to make a paradigmatic change 
from the positivism paradigm, which emphasizes statutory regulations to become law based on the constructivism paradigm, emphasizing diversity and freedom. This diversity and freedom are tied to values and contexts. It is because the constructivism paradigm is value-laden or full of values.

Referring to Rahardjo [17], values are in the realm of epistemology and are further elaborated in a table of practical issues. It means that every policy (in the realm of methodology) in the constructivism paradigm is always tied to values (in the realm of epistemology) because there are connective, sequential, and strategic relationships between the three. The ontology underlies epistemology, and epistemology underlies the methodology and methodology underlies the method.

At this point, it can be understood that the law for the traditional Bajo tribe is a different agreement from the meaning of law in the positivism paradigm, namely the laws and regulations. This positivism view cannot be used in assessing the existence of law in the traditional Bajo community. It is not correct to state that in the conventional Bajo community, there are no laws because there are no regulations.

\section{Conclusion}

Currently, there are no specific regulations governing land use in the community because the orientation of land use is still focused on land. In this case, if the Government wants to regulate land use in coastal waters, there are three essential factors to consider, namely: a) Strong economic, social and cultural linkages between the community and the land; b) There are different geographical conditions between traditional community settlement lands that are underwater and closely related to the ocean with land conditions on land that have their own characteristics; c) There is a land tenure pattern that is unique to the community.

The traditional Bajo community in making order in land use for settlements can be studied paradigmatically, namely: ontology, and the Bajo people identify themselves as sea people to build houses on the beach. Epistemology: there is intensive interaction between the community and emphasizes solidarity, methodology: the organization conducts deliberations in formulating an agreement in the form of boundaries of land use and distances between houses. In the method (practical) realm, there is a distance of $1.5 \mathrm{~m}^{2}$ and requests for neighbors' permission before building a building.

\section{References}

[1] R. Lasabuda, "Pembangunan wilayah pesisir dan lautan dalam perspektif Negara Kepulauan Republik Indonesia," J. Ilm. Platax, vol. 1, no. 2, pp. 92-101, 2013.

[2] D. Djubedi, Hak ulayat laut di era otonomi daerah. Yogyakarta; Genta Press, 2015.

[3] D. Mead and M. Lee, "Mapping Indonesian Bajau Communities in Sulawesi," 2007.

[4] Ernis, Penelitian hukum tentang konsistensi penggunaan dan pemanfaatan tanah sesuai dengan undang-undang no. 26 tahun 2007 tentang penataan ruang. Jakarta; Badan Pembinaan Hukum Nasional, 2007.

[5] M. A. Mahfud, Menggagas Pendaftaran Tanah Terpadu Di Pantai: Telaah Keadilan Dworkinian Tentang Permukiman Masyarakat Tradisional Suku Bajo Di Sulawesi Tenggara, Semarang; Universitas Diponegoro, 2019.

[6] Z. T. Kulzhanova and G. T. Kulzhanova, "Legal Culture as the Determinant of Value Orientations in Youth in the Society of the Transition Period (Philosophical Analysis).," Int. J. Environ. Sci. Educ., vol. 11, no. 12, pp. 4997-5008, 2016. 
[7] D. Zartner, "The Culture of Law: Understanding the Influence of Legal Tradition on Transitional Justice in Post-Conflict Societies," Ind. Int'l Comp. L. Rev., vol. 22, pp. 297, 2012.

[8] L. M. Friedman, "The Concept of the Self in Legal Culture," Clev. St. L. Rev., vol. 38, pp. 517, 1990.

[9] M. Menachem, "Three Approaches to Law and Culture," Cornell Law Rev., vol. 96, no. 4, p. 849, 2011.

[10] S. Lavi, "Turning the Tables on Law and: A Jurisprudential Inquiry into Contemporary Legal Theory," Cornell L. Rev., vol. 96, pp. 811, 2010.

[11] D. N. Schiff, "Socio-legal theory: social structure and law," Mod. Law Rev., vol. 39, no. 3, pp. 287-310, 1976.

[12] S. Rahardjo, Hukum dalam Jagat Ketertiban (Bacaan Mahasiswa Program Doktor Ilmu Hukum Universitas Diponegoro). Jakarta; Uki Press, 2006.

[13] Rahardjo, Ilmu hukum. Bandung; Citra Aditya Bakti, 2012.

[14] S. Rahardjo, Membangun dan merombak hukum Indonesia: sebuah pendekatan lintas disiplin. Yogyakart; Genta Pub., 2009.

[15] P. S. Berman, "Law as Culture," Am. J. Comp. Law, no. 57, pp. 104, 2005.

[16] P. S. Berman, "Global Legal Pluralism," South. Calif. Law Rev., vol. 80, pp. 1155, 2007

[17] E. G. Guba and Y. S. Lincoln, "Competing paradigms in qualitative research," Handb. Qual. Res., vol. 2, no. 163-194, p. 105, 1994. 